v. I5. exparanar erewor ('to love them') is apparently due to Wilkins. V preserves the true Coptic.

This chapter does not add much to the evidence obtainable from the last. So far as it goes its evidence supports the conclusions already drawn.

We may now summarise as shortly as possible the results obtained from the examination of specimen passages in all the MSS. The grouping of the MSS is quite clear. A common lacuna shews that all are derived from one, probably near, ancestor, but they form two distinctly marked groups, neither of which has a monopoly of the true text. A critical edition of the Pentateuch is needed, based on the agreement of $\mathrm{A}$ and $\mathrm{V}$, and recording at least all the variants of these two MSS. There are a few readings of interest in $M$, but on the whole it contributes little to our knowledge of the text. The necessity for collating and using $A$ and $V$, in addition to the printed editions, for a critical edition of the Greek Septuagint has not been so clearly demonstrated. It has been shewn that such a course would be desirable if it did not involve too much delay. A strong case has however been made out, as it seems to me, for quoting the readings of $\mathrm{A}$ in Genesis and wherever $\mathrm{L}$ is defective, and of $\mathrm{V}$ in Deuteronomy. The great probability that Wilkins has in certain cases mended his text by retranslating from the Greek makes it all the more desirable to control his edition throughout by the collation of a MS of the first group.

A. E. Brooke.

\title{
ON THE ORDINATION OF THE EARLY BISHOPS OF ALEXANDRIA.
}

I SHOULD like to be allowed to say a word with reference to Mr. Brooks' interesting note on this subject, contained in the JournaL of July, r $90 \mathrm{r}$, pp. 6 I $2 \mathrm{f}$.

Hitherto substantially our only real reason for supposing that the Alexandrian 'succession' was exceptional in its method, has been .a famous statement of Jerome's, that 'from the days of St. Mark the Evangelist down to the episcopates of Heraclas and Dionysius (A. D. 233-265) the presbyters at Alexandria used always to give the name of bishop (nominabant) to one whom they chose out of their own number and placed upon the higher grade, just as if an army were making a general, or deacons were choosing one of themselves whose activity they knew, and calling him archdeacon. For what, except ordination, does a bishop do which a presbyter does not?' 
This statement is possibly somewhat ambiguous, but seems to mean, what it was certainly taken to mean by ninth-century Latin writers ', who repeated it without hesitation or unwillingness, that the bishops at Alexandria received no new consecration on acceding to the episcopate, but simply election by their fellows; and this was taken by these Western writers to be a survival of a substantial identity between the 'presbyterate' and the 'episcopate,' which existed originally, and was indicated by the interchangeableness of the names.

A certain Melkite patriarch of Alexandria, of the tenth century -an Arab, Sa'id Ibn Batrik, who took the Greek name of Eutychius, though he does not appear to have known Greek-has been hitherto the only presumably independent supporter of Jerome's statement. But his date, his amazing ignorance, his divergence on many points from Jerome, and the fact that an almost contemporary writer, Severus ${ }^{2}$, who is not quite so ignorant, differs from him wholly in his account of the origin of the Alexandrian church, deprive his support of any assignable value.

But now Mr. Brooks produces a new and important piece of evidence from a letter of Severus, the Monophysite Patriarch of Antioch, written in Egypt, during his banishment A. D. $518-538$. Severus says that the bishop of Alexandria 'used in former days to be appointed by presbyters,' which is simply Jerome's statement without his details. Jerome's statement was commonly repeated in the West; but, unless there is evidence, which I do not know of, that Severus knew Latin writers and Jerome in particular, his statement must be taken to be independent of Jerome's, and derived, like Jerome's, from a tradition at Alexandria itself.

Of course if the story about Poemen the hermit, adduced by Dom Butler and now again by the editor of $J . T . S$. (see as above, p. 613), can be taken as additional proof that this tradition existed in Egypt towards the end of the fourth century, the supposed fact would rest upon a still surer basis. 'Some heretics' are said to have visited the celebrated hermit and 'spoken against the archbishop of Alexandria as having received his ordination from presbyters.' We are only told this because the hermit exhibited such meekness under this imputation (unfortunately for us) as to make no rejoinder. What then was the meaning of their remark?

Poemen's date appears to be wrongly given in the Dict. of Ch. Biog.

1 Amalarius de eccl. offic. ii $13, P$. L. cv rogo; Pseud. Alcuin de divtn. offic. 37, P. L. ci 1237 .

$=$ The Patriarchal Chronicle of this Severus, bishop of Eshmunain, is about to be published, with translation and commentary, by Mr. Evetts : see Egypt Exploration Fund, archaeological report, 1900-1901, p. 79. 
as 390-460. For Rufinus visited Poemen, among other famous anchorites, and received his benediction, about A. D. 375 (Hist. Eccl. ii $[\mathrm{xi}] 8)$. The archbishop, then, whom the heretics referred to on the occasion of their undated visit may very probably have been Athanasius (died A. D. 373). Now that Athanasius was not ordained as suggested we know '. The custom as Jerome reports it had been extinct for a century. But we also know that innumerable slanders were current among the Arians about his ordination; and the repetition of one of these was more likely than anything else to stir the indignation of an orthodox monk, which was presumably the intention of his heretical visitors. Probably then the statement about the Alexandrian archbishop is simply a personal slander, and has nothing to do with the history of the Alexandrian succession.

But, apart from this story, the plain statements of Jerome and Severus are very hard to resist. They indicate a distinct historical tradition, going back to the fourth century. Most historians, German and English, appear to think Jerome's evidence by itself enough. But I think they greatly underrate the contrary evidence of Origen. Origen lived and taught at Alexandria till A.D. 23I, when he was forty-five. All this time the Alexandrian bishop differed (if Jerome's account be true) from the presbyters in honour and office, not in essential order. Shortly after this Origen suffered treatment at the hands of the bishops of Alexandria and the neighbourhood which would dispose him to scrutinise their jurisdiction somewhat jealously; for whlle a mixed synod of Egyptian bishops and presbyters had banished him from Alexandria, but not deposed him from his presbyterate, for a breach of canonical discipline, a synod of bishops alone, at the instance of Demetrius of Alexandria, had deposed him, as he and his friends thought, unjustly. In 23I he left Alexandria. Two years afterwards Heraclas (his old pupil and friend) became bishop in succession to Demetrius, and (according to Jerome) the separate ordination of the Alexandrian bishop and his consequent differentiation from the presbyters began-i. e., presumably, was provided for, and carried into effect at the ordination of his successor Dionysius (A. D. 249). Origen therefore, on this hypothesis, had intimate experience of a gradual change resulting in the clear differentiation at Alexandria of the episcopate from the presbyterate, and every reason for scanning with some jealousy the

' We have the letter of the Alexandrian synod of Egyptian bishops, A.D. 339, to 'the bishops of the Catholic Church.' 'To the fact that the majority of us ordained

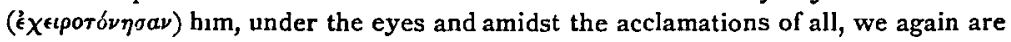
better witnesses than those who were absent and who speak falsely-we who ordained him.' Moreover the case of Colluthus (as I have shown in The Church and the Ministry, p. 126) shows that at Alexandria in 324 there was no tendency at all to confuse the status of bishop and presbyter. 
exaltation of the bishop. And he shows nowhere any disposition to spare bishops castıgation which he thinks well merited. Moreover such a change in ecclesiastical status could occur nowhere without some jealousy or friction. Yet writing against Celsus ${ }^{1}$ in the year of Heraclas death and Dionysius' succession he compares 'ecclesiae of God' with' the civil 'ecclesiae' at Athens, Corinth, and Alexandria ; he compares in each case the archon (bishop), the councillors (presbyters), and the people; he finds the Christian churches characterised by 'mildness and stability': if fault is to be found with some of the Christian 'councillors or archons,' it is because they are found to live indolent lives compared with some of their more energetic fellows. Neither here nor elsewhere -and Origen often alludes to bishops and presbyters-does he give any hint that bishops were exalting their order at the expense of presbyters. Indeed he assumes for the episcopate a completely stable and traditional position clearly distinct from the presbyterate. Moreover in his homilies on Numbers (after A. D. 244), when he is desiring a more religious method of appointing bishops than was customary, he speaks of bishops nominating their successors (giving preference to their relations), of popular nomination, and of nomination by 'one of the priests' 2 : but he does not contemplate election by the body of presbyters, and he does imply that the bishop was, after designation, ordained by laying on of hands. $\mathrm{He}$ is not talking, in this passage, specially about Alexandria, and he had long ceased to live there; but Caesarea was not very far off, so that he could hardly have ignored any markedly different conditions in the great neighbouring church of Alexandria. And Alexandrian tradition itself in the fourth century certainly assigned the power in episcopal election to the people, not to the presbyters.

I think Origen's language as a whole is not generally taken into account, and it renders very difficult the acceptance of any tradition which would either (I) represent his long life as synchronising with a gradual exaltation of the episcopate, which would certainly have involved some jealousy and friction, or (2) represent the Alexandrian church of his experience as differing from other churches. I have cited the passage in Origen more at length in The Church and the Ministry, pp. $127 \mathrm{f}^{3}$. But I refer to the matter here in connexion with the fresh evidence, because it is customary to treat any one who hesitates to accept it as simply blinded by ecclesiastical prejudice. Now I'see no ecclesiastical reason which should hinder us, any more than the

1 Ad Cels. iii zo.

${ }^{2}$ In Num. hom. xxii 4 .

3 Where I have stated Origen's age at Heraclas' accession as 'thirty-eight,' by mistake for forty-eight. 
Western theologians alluded to above, from accepting the evidence: Severus of Antioch in recording the tradition ${ }^{1}$ shows that in his mind it carried with it no consequences such as modern controversy has sometimes attached to it. But I do see in Origen's language a commonly ignored reason why we should still regard the matter as involved in doubt.

Charles Gore.

\section{THE ORIGINAL ORDER AND CONTENTS OF OUR OLDEST MS OF ST. CYPRIAN.}

THE problem of the order and arrangement of the earliest collections of St. Cyprian's works has attracted of late years a good deal of attention-see Sanday The Cheltenham list... of the writings of Cyprian in Studia Biblica iii 274-303 [1891], Gotz Geschichte der cyprianischen Litteratur bis zu der Zeit der ersten erhaltenen Handschriften [1891], Turner Two early lists of S. Cyprian's works [Classical Review, May, 1892], and Harnack Geschichte der altchristlichen Litteratur i $688 \mathrm{ff}$ [r893]. It seemed therefore worth while to establish once for all the original order of the treatises in the oldest of all our Cyprianic MSS, Paris. lat. 10592, known since Hartel's edition as S (it came from the collection of Seguier); and with that view I made an examination of the MS, not so detailed as I could have wished, but I think sufficient for the purpose, in September, I90I. Such an examination was doubly necessary: in the first place, because Dr. Sanday-whom Harnack follows-has in his list of the contents of S (Studia Biblica iii 283; Harnack Gesch. der altchr. Litt. i 697) omitted two treatises of which $\mathrm{S}$ gives portions, though not the commencement or title; in the second place, because even Hartel, whose preface (pp. iii-v) does indicate all the fragments still contained in $\mathrm{S}$, did not make any investigation of the extent of the lacunae with a view to fixing the pristine contents of the MS.

The original hand wrote foll. 4-98, I0I-1 55 : foll. I-3, 99-100, are quite late insertions, intended merely to complete treatises imperfect in the then state of the MS, and may be entirely neglected. One quaternion of the work of the original scribe has been misplaced, and now stands as foll. 53-60, whereas it ought to come immediately after fol. II. There are lacunae between foll. 34,36 (fol. 35 is a mere fragment, not contınuous with either fol. 34 or fol. 36 ), between foll. 82-83, between foll. 90-9I, between foll. 98-10 (foll. 99, 100 are insertions), and between foll. 147-148. The margins seem to have

${ }^{1}$ See J. T. S., July, rgor, p. 612. 